\title{
AUDIT SISTEM INFORMASI PADA TATA USAHA SDN 1 TANJUNG SARI NATAR LAMPUNG
}

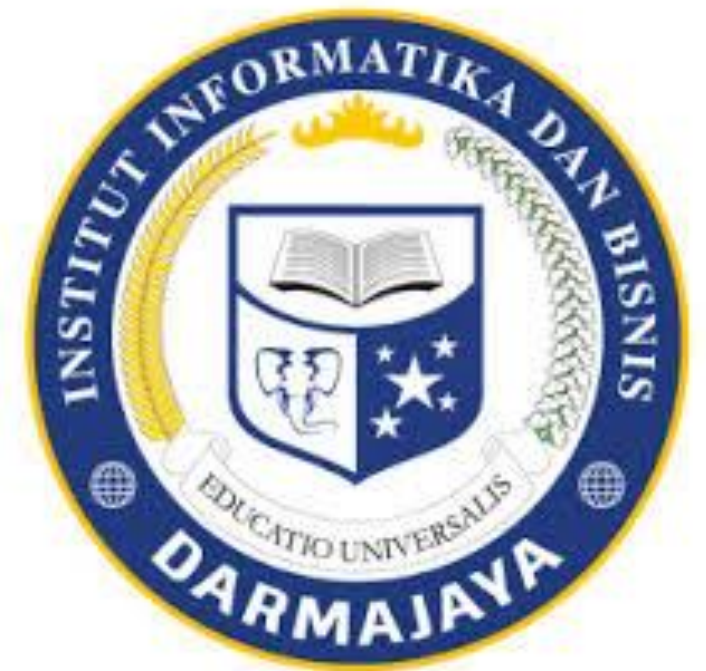

Di Susun Oleh :

\begin{abstract}
M Ridho Tri Putra
$1611058003 \mathrm{P}$
\end{abstract}

Mata Kuliah : Audit Sistem Infromasi 7SI-P3

\author{
SISTEM INFORMASI \\ FAKULTAS KOMPUTER \\ DARMAJAYA \\ BANDAR LAMPUNG \\ 2019
}




\section{BAB I \\ PENDAHULUAN}

\section{A. Latar Belakang}

Pendidikan merupakan upaya untuk membentuk manusia seutuhnya dan jelas membutuhkan waktu yang relativ lama bahkan berlangsung seumur hidup.Untuk mewujudakan dan menjadikan manusia seutuhnya perlu adanya tenaga pendidik dan tenaga kependidikan yang cakap dalam mengelola lembaga pendidikan dan mendesainnya sebaik mungkin.

Keberadaan tenaga adminisrasi sekolah (tata usaha sekolah) akan sangat mendukung meningkatkan mutu dan pelayanan pendidikan apabila mereka memiliki kualifikasi dan kompetensi minimal sesuai yang disyaratkan.

Tujuan pengembangan kualitas tenaga administrasi sekolah (tata usaha sekolah) adalah untuk memperbaiki prestasi kerja tenaga administrasi sekolah (tata usaha sekolah) dalam mencapai hasil kerja yang ditetapkan, perbaikan ini

pengembangan tata usaha disekolah tersebut tidak mendapat perhatian yang serius dari kepala sekolah bahkan cenderung terabaikan, baik dari perencanaan, koordinasi, maupun penganggarannya. Pengembangan tata usaha sekolah dianggap kurang penting sehingga jarang sekali mengadakan kegiatan pengembangan, kemudian tata usaha di sekolah tersebut jarang mendapat kesempatan untuk mengikuti kegiatan pelatihan, ataupun kegiatan pengembangan.

Permasalahan diatas dapat dilihat dengan adanya gejala-gejala sebagai berikut

1. Adanya tata usaha sekolah yang kurang mampu mengelola administrasi sekola.

2. Adanya tata usaha sekolah yang kurang mampu mengoperasikan computer.

3. Adanya tata usaha sekolah yang belum pernah mengikuti kegiatan pelatihan.

4. Tidak ada anggaran untuk kegiatan pengembangan tata usaha sekolah. 


\section{B.Sejarah Sekolah}

SD Negeri 1 Tanjung Sari Natar berdiri pada tahun 1981 dengan nama SD Inpres Sarirejo, beralamat di Dusun Sarirejo Desa Natar Kecamatan Natar

Kabupaten Lampung Selatan. Kemudian berdasar SK Gubernur Lampung

Th 1985 berubah nama menjadi SD Negeri 1 Natar.

Sejak berdiri hingga sekarang, di SD Negeri 1 Natar telah

beberapa kali mengalami pergantian pimpinan antara lain :

Tahun Pelajaran $1981-1995$ : Drs. Bahiki

Tahun Pelajaran 1995 - 2005 : Drs. M. Kasim

Tahun Pelajaran 2005 - 2010 : Suratinem, S.Pd

Tahun Pelajaran 2010 - sekarang : Hj. Etika Murti, S.Pd 
SDN 1 Tanjung Sari Natar

* Jenis Perusahaan

* DIVISI

* Tahun Berdiri

* Bergerak di Bidang

* Produk Yang di hasilkan

* Penghargaan yg di Raih

* Visi

Misi
: Perusahaan Pendidikan

: Tata Usaha

: 1981

: Pendidikan

: Siswa yang berprestasi

: Juara Uks tingkat Kabupaten

: Membuat siswa beriman dan disiplin

: Melaksanakan pembelajaran, aktif, kreatif , efektif

Menyenangkan dan inovatif

Meningkatkan iman dan takwa sebagai landasan utama

Menanamkan budaya tertib disipilin

* Pengaruh terhadap Lingkungan :

-Membuat jarak rumah warga di lingkungan sekolah semakin dekat sehinnga warga setempat menyekolahkan anaknya di sekolah tersebut, agar biaya yang dikeluarkan tidak banyak.

- Adanya aktivitas warga yang berjualan di sekitar sekolah

- Membuat lingkungan sekitar semakin strategis untuk menimba ilmu di sekolah 
C. STRUKTUR ORGANISASI SEKOLAH

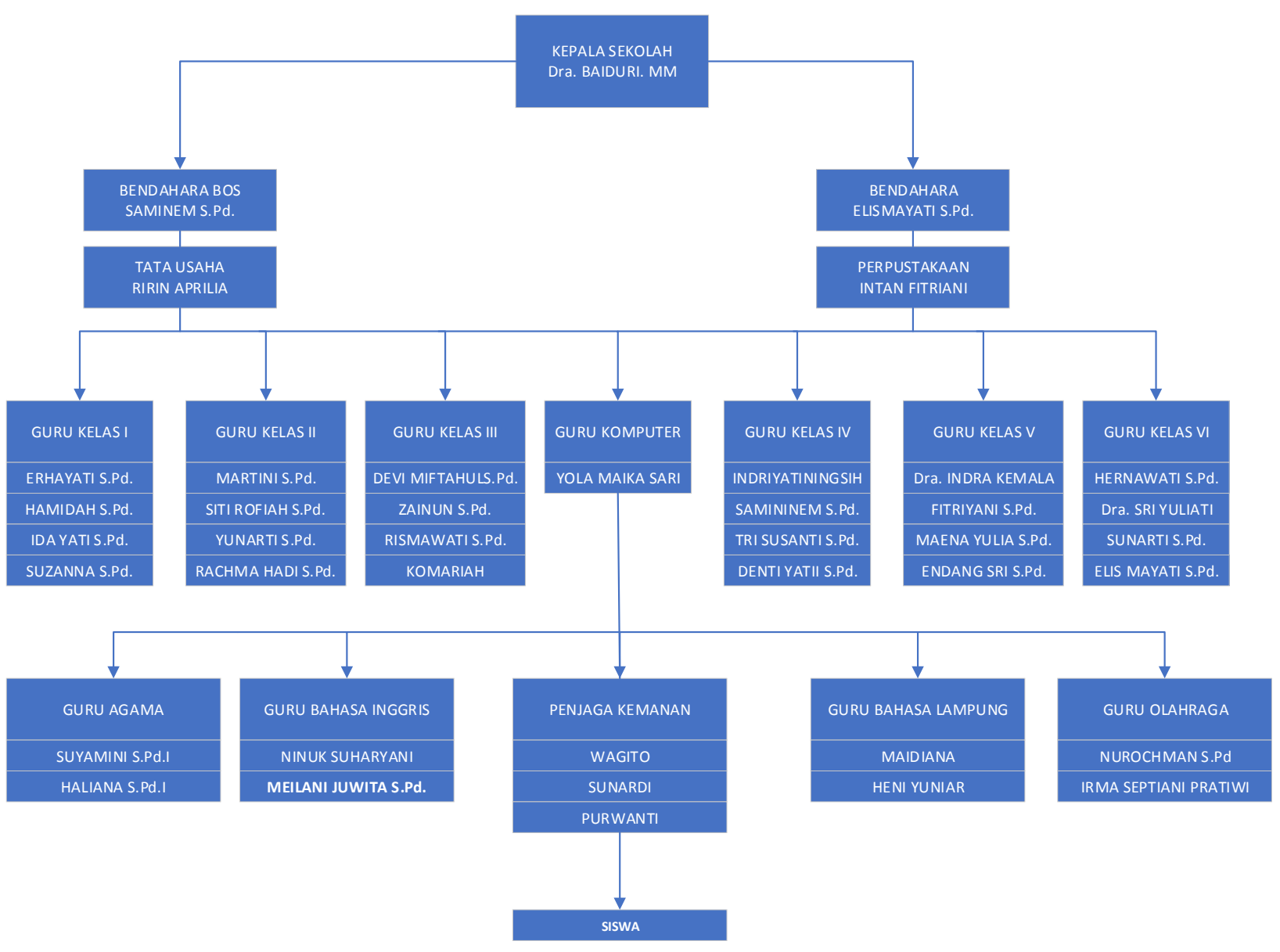


TRUKTUR TATA USAHA SD 1 TANJUNG SARI

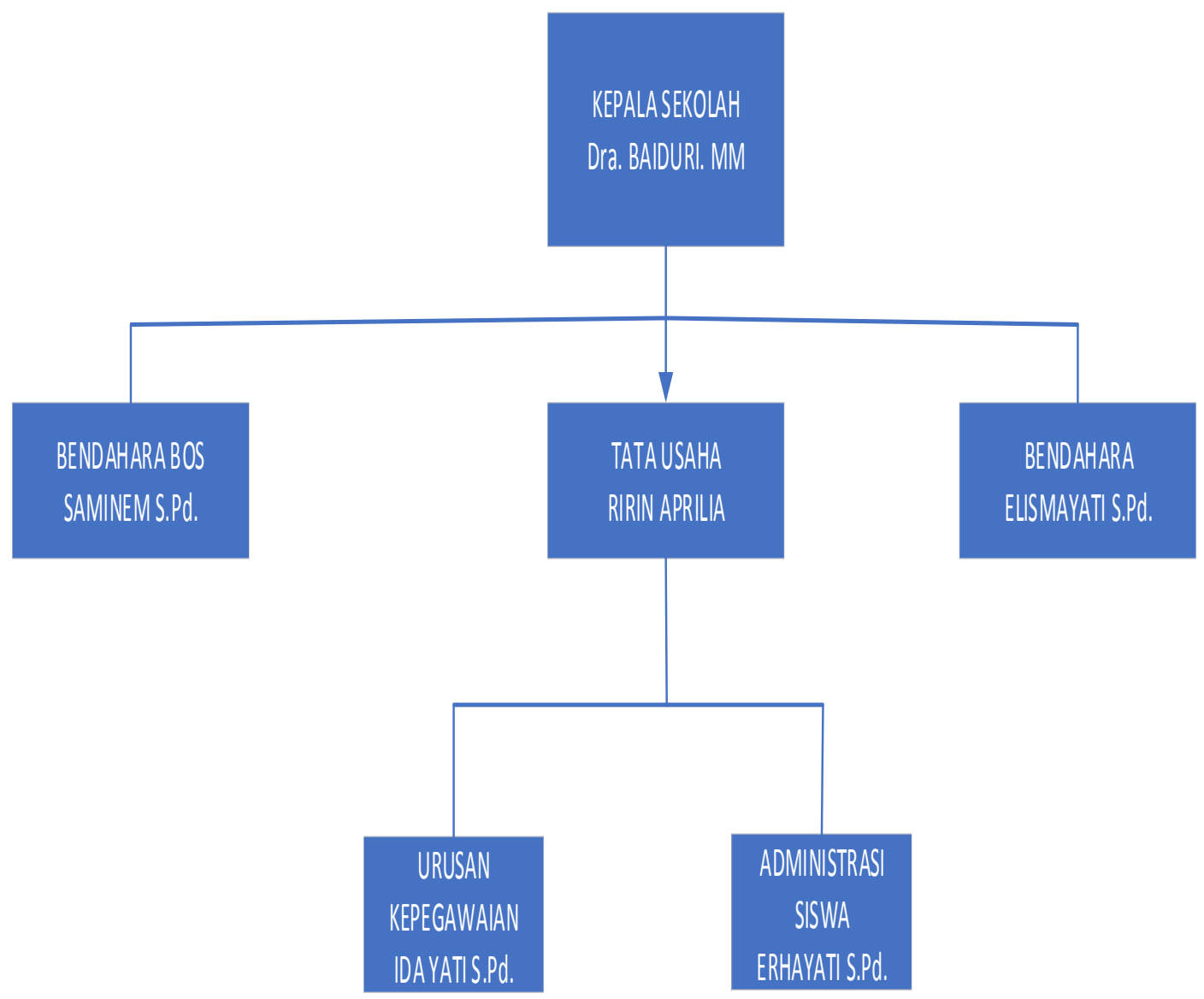




\section{BAB II}

\section{TINJAUAN PUSTAKA}

\subsection{Tinjauan Pustaka}

Evaluasi terhadap tata kelola teknologi informasi menggunakan COBIT framework telah banyak diteliti dan hasil rekomendasinya sudah banyak membantuk perusahaan memperbaiki tata kelola teknologi informasi menjadi lebih. Seperti penelitian oleh (Marrone et al. 2010) tentang menyelaraskan teknologi informasi dengan bisnis, (Goldschmidt et al. 2007) berpendapat bahwa teknologi informasi yang dikelola dengan baik akan menghasilkan keselarasan antara bisnis dan teknologi informasi.

Penelitian serupa juga pernah dilakukan oleh (Widyati Kania, 2011). Perpustakaan Nasional RI sejak tahun 2008 telah memanfaatkan teknologi Radio Frequency Identification (RFID) untuk meningkatkan kualitas layanannya. Tatakelola teknologi RFID dan pengukuran tingkat kemapanan teknologi RFID dilakukan pada fungsi yang sudah berjalan yaitu di Kelompok Layanan Terbuka. Penelitian yang dilakukan bersifat evaluatif dengan pendekatan pada efektifitas dan efisiensi tatakelola TI yang dilaksanakan di Perpustakaan Nasional. Analisa dilakukan dengan menggunakan prosedur standar COBIT 4.1 yang menerapkan mekanisme kontrol yang terdapat dalam 34 kendali proses dibawah 4 domain.

Untuk meningkatkan tingkat kemapanan berdasarkan COBIT 4.1 dilakukan penentuan prioritas dan target dari perbaikan yang akan dilakukan. Enam kendali proses yang mendapat nilai terendah dan dapat dijadikan sebagai 5 prioritas utama.

Selain itu (Irania Dwi Wijayanti, 2016), melakukan Analisis Maturity Level Process Teknologi Informasi Menggunakan Framework COBIT 4.1 (Studi Kasus pada BSI UMY). Dan yang digunakan adalah framework COBIT 4.1 menggunakan 2 proses TI. Pengumpulan data ini dilakukan dengan cara menyebarkan kuesioner dan wawancara. Kedua metode tersebut berpatokan pada framework COBIT 4.1. kuesioner ini dilakukan dengan dua tahapan, tahapan pertama yaitu kuesioner skala 
prioritas yang dimaksudkan untuk mendapatkan proses Teknologi Informasi (TI) yang sering digunakan di Biro Sistem Informasi UMY, tahapan kedua kuesioner maturity level dimaksudkan untuk mengetahui tingkat kematangan teknologi informasi di Biro Sistem Informasi. Setelah mengetahui tingkat kematangan di Biro Sistem Informasi maka dapat memberikan rekomendasi yang lebih baik untuk diterapkan di Biro Sistem Informasi UMY.

Penelitian ini menilai tingkat kematangan UKSW dalam menerapkan teknologi informasi untuk mendukung proses bisnis yang dilakukan oleh (Maria \& Haryani, 2011). Penelitian menghasilkan rekomendasi bagaimana tata kelola teknologi informasi harus ditingkatkan berdasarkan pada kerangka COBIT. Maria merekomendasi untuk meningkatkan kinerja UKSW di masa depan maka evaluasi teknologi informasi harus terus dilakukan dan kualitas layanan teknologiinformasi lebih ditingkatkan.

COBIT framework merupakan model yang paling tepat dan telah banyak digunakan untuk melakukan pengukuran tingkat kematangan terhadap berbagai bidang organisasi yang mengimplementasikan teknologi informasi dalam proses bisnisnya. Dibandingkan penelitian terhadulu penulis melakukan tahapan pengumpulan data secara mendalam dengan proses TI berbeda dari yang terdahulu. Penulis melakukan penelitian pada BSI UMY menggunakan 3 proses TI. Pengumpulan data dilakukan dengan kuesioner maturity level, kuesioner CSF dan KPI, dan wawancara. 


\section{Landasan Teori}

\section{Tata Kelola Teknologi Informasi}

Tata kelola TI (IT Governance) merupakan suatu struktur dan proses yang saling berhubungan serta mengarahkan dan mengendalikan organisasi dalam mencapai tujuan organisasi melalui nilai tambah dan menyeimbangkan antara risiko dan manfaat dari teknologi informasi serta prosesnya.

\section{Fokus Area Tata Kelola Teknologi Informasi}

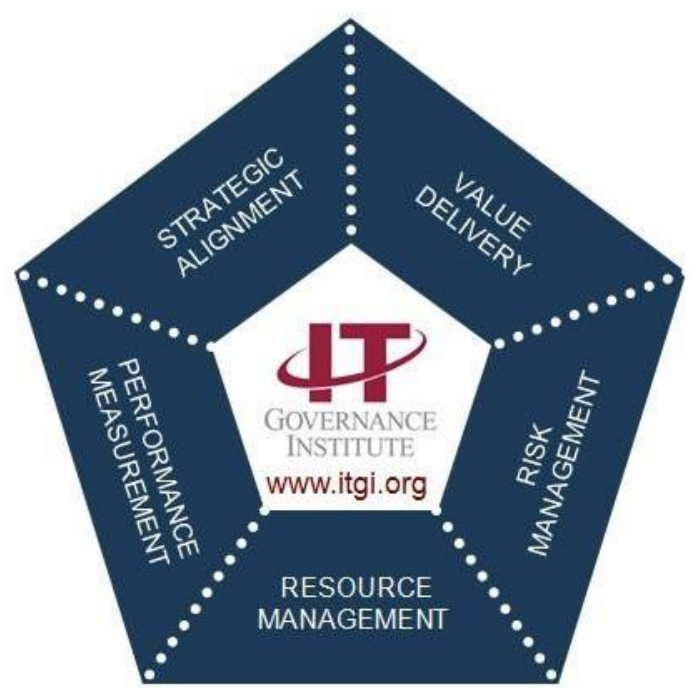

Gambar 2.1 Fokus Area

(Sumber: ITGI, 2007)

Terdapat 5 area penting yang perlu diperhatikan dalam tata kelola TI seperti pada Gambar 2.1, setiap area mempunyai standar pengaturan yang diuraikan pada COBIT. Berikut adalah lima area yang menjadi fokus utama tata kelola TI, yaitu (ITGI,2007):

1. Strategic Alignment, membahas tentang bagaimana mencapai visi dan misi organisasi yang selaras dengan bisnis organisasi tersebut. 
2. Value Delivery, membahas tentang bagaimana mengoptimalkan nilai tambah TI guna pencapaian visi dan misi organisasi.

3. Resources Management, membahas tentang bagaimana sumber daya dan infrastruktur dapat mencukupi dan penggunaanya yang optimal. Permasalahan ini berkaitan dengan investasi yang optimal berkaitan dengan TI yang ada, dan manajemen yang sesuai, sumber daya TI yaitu aplikasi, informasi, infrastruktur dan sumber daya manusia. Hal-hal yang penting berhubungan dengan optimisasi pengetahuan dan infrastruktur.

4. Risk Management, membahas tentang bagaimana mengidentifikasi resiko yang mungkin ada dan bagaimana mengatasi dampak dari risiko tersebut.

5. Performance Measurement, membahas tentang bagaimana mengukur dan mengawasi kinerja dari TI dan menyesuaikan penggunaan TI dengan kebutuhan bisnis organisasi.

Penerapan Tata Kelola Teknologi Informasi dapat dibedakan berdasarkan tujuan jangka pendek dan tujuan jangka panjang. Dalam jangka pendek TKTI dapat digunakan untuk menekan biaya operasional TI dengan cara mengoptimalkan operasi-operasi yang ada di dalamnya. Hal ini dapat dicapai melalui kendali-kendali yang diterapkan pada setiap proses penggunaan sumberdaya TI dan penanganan resiko-resikonya. Sedangkan dalam jangka panjang penerapan TKTI membantu perusahaan untuk tetap fokus terhadap nilai strategis TI dan memastikan penerapan TI tetap mendukung pencapaian tujuan perusahaan.

\subsubsection{COBIT}

Control Objectives for Information and related Technology (COBIT) adalah suatu panduan standar praktek manajemen teknologi informasi dan sekumpulan dokumentasi best practices untuk tata kelola TI yang dapat membuat auditor manajemen, dan pengguna untuk menjembatani pemisah (gap) antara resiko bisnis, kebutuhan pengendalian, dan permasalahan-permasalahan teknis. COBIT dikembangkan oleh Information Technology Governance Institute (ITGI), yang merupakan bagian dari Information System Audit and Control Association (ISACA) pada tahun 1992. 
Prinsip dasar COBIT meliputi (Simonsson \& Johnson, 2006):

1. Business Information Requirement yaitu berupa informasi, dimana informasi harus terdapat unsur effectiveness (efektif), efficiency (efisien), confidential itu (keyakinan), integrity (integritas), availability (tersedia), compliance (pemenuhan), reliability (dipercaya).

2. IT Resource, terdiri dari pengguna (people), aplikasi (application), teknologi (technology), infrastruktur (infrastructure), informasi (information), Database Management System, Hardware, Software dan Multimedia.

3. High Level IT Process, terdiri dari: Proses TI (Plainning and Organization (PO), Acquisition and Implementation (AI), Delivery Support (DS), dan monitoring and evalution (ME); IT Process (IT Strategy, Computer operation, Incident Handling, Acceptance testing, Change management, Contingency planning dan Problem Management), Activities (Record new problem, Analyse, Propose, solution, Monitoring solution dan Record known Problem).

COBIT berisi tujuan pengendalian, petunjuk audit, kinerja dan hasil metrik, factor kesuksesan dan model kedewasaan. Untuk memajukan pemikiran dan standar internasional dalam mengarahkan dan mengendalikan teknologi informasi sebuah organisasi.

COBIT 4.1 merupakan sebuah kerangka menyeluruh yang dapat membantu perusahaan dalam mencapai tujuannya untuk tata kelola dan manajemen TI perusahaan. Secara sederhana, COBIT 4.1 membantu perusahaan menciptakan nilai optimal dari TI dengan cara menjaga keseimbangan antara mendapatkan keuntungan dan mengoptimalkan tingkat resiko dan penggunaan sumber daya. COBIT 4.1 memungkinkan TI untuk dikelola dan diatur dalam cara yang lebih menyeluruh untuk seluruh lingkup perusahaan, meliputi seluruh lingkup bisnis dan lingkup area fungsional TI, dengan mempertimbangkan kepentingan para stakeholder internal dan eksternal yang berhubungan dengan TI. COBIT 4.1 bersifat umum dan berguna untuk segala jenis ukuran perusahaan, baik itu sektor komersial, sektor non profit atau pada sektor pemerintahan atau publik. 
BAB III

\title{
Pengumpulan Data Quisioner Wawancara
}

Alamat

$\begin{array}{ll}\text { Alamat } & : \text { JL BERINGIN } \\ \text { RT / RW } & : 13 / 7 \\ \text { Dusun } & : \text { Tanjungsari } \\ \text { Desa / Kelurahan } & : \text { TANJUNGSARI } \\ \text { Kecamatan } & : \text { Kec. Natar } \\ \text { Kabupaten } & : \text { Kab. Lampung Selatan } \\ \text { Provinsi } & : \text { Prov. Lampung } \\ \text { Kode Pos } & : 35362\end{array}$

Yang di wawancara

$\begin{array}{ll}\text { Nama } & : \text { Ririn Aprilia } \\ \text { Divisi } & : \text { Staff Tata Usaha }\end{array}$

Tanggal Wawancara

$\begin{array}{ll}\text { Tanggal } & : \text { 25 Januari } 2019 \\ \text { Jam } & : 10.15 \text { a.m. }\end{array}$

Data Quisioner :

\author{
Quisioner Manajemen \\ 6 orang (Divisi Staff Tata Usaha) \\ Quisioner User(siswa) \\ 40 orang acak (random)
}

Tanggal Quisioner
Tanggal
: 25 Januari 2019
Jam
: 10.30 a.m. 
KUESIONER TATA USAHA PADA SEKOLAH DASAR

(MANAJEMEN)

Keterangan Pilihan Jawaban:

SB:SANGATBAIK B: BAIK| C: CUKUP TB: TIDAKBAIK STB: SANGATTIDAKBAIK

\begin{tabular}{|c|c|c|c|c|c|c|c|c|c|c|c|}
\hline \multirow[t]{2}{*}{ No } & \multirow[t]{2}{*}{ Pernuataan } & \multicolumn{5}{|c|}{ Performance } & \multicolumn{5}{|c|}{ Expectasi } \\
\hline & & SB & $\mathrm{B}$ & $\mathrm{C}$ & TB & STB & $\mathrm{SB}$ & $\mathrm{B}$ & $\mathrm{C}$ & TB & STB \\
\hline \multicolumn{12}{|c|}{ ME 1 MengawK天 DAN MENGEVALUASI KINERIA IT } \\
\hline \multicolumn{12}{|c|}{ ME1.1 Penderatan Pedantalera } \\
\hline 1 & $\begin{array}{l}\text { Apakah proses pemantauan di Tata } \\
\text { Usaha sudah berialan dengan baik }\end{array}$ & & & & & & & & & & \\
\hline 2 & $\begin{array}{l}\text { Apakah Pengawasan kontribusi IT } \\
\text { Terhadap Tata Usaha sudah berialan } \\
\text { dengan baik }\end{array}$ & & & & & & & & & & \\
\hline \multicolumn{12}{|c|}{ 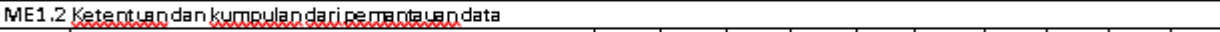 } \\
\hline 1 & $\begin{array}{l}\text { Apakah Vang dilakukan dalam standar } \\
\text { kineria Tata Usaha sudah berialan } \\
\text { dengan baik }\end{array}$ & & & & & & & & & & \\
\hline 2 & $\begin{array}{l}\text { Bagaimana Pelaporan data di dalam tata } \\
\text { usaha }\end{array}$ & & & & & & & & & & \\
\hline \multicolumn{12}{|c|}{ ME1.3 Metode Rendontald } \\
\hline 1 & $\begin{array}{l}\text { Metode yang di terapkan dalam Tata } \\
\text { Usaha }\end{array}$ & & & & & & & & & & \\
\hline 2 & $\begin{array}{l}\text { Apakah Sistem yang berialan dalam tata } \\
\text { usaha sudah berialan dengan baik }\end{array}$ & & & & & & & & & & \\
\hline \multicolumn{12}{|c|}{ ME1.4 Pemerikspan Kinerja } \\
\hline 1 & $\begin{array}{l}\text { Perbaikan Kineria dalam Tata Usaha } \\
\text { sudah dilakukan dengan baik }\end{array}$ & & & & & & & & & & \\
\hline 2 & $\begin{array}{l}\text { Pengecekan yang dilakukan dalam Tata } \\
\text { Usaha sudah berialan dengan baik }\end{array}$ & & & & & & & & & & \\
\hline \multicolumn{12}{|c|}{ ME1.5 Relarean Devendan Ekgekutif } \\
\hline 1 & $\begin{array}{l}\text { Pelaporan Pembukuan Tata U saha sudah } \\
\text { sesuai dengan apa yang sudah di } \\
\text { tetapkan dalam standar yang baik }\end{array}$ & & & & & & & & & & \\
\hline 2 & $\begin{array}{l}\text { Anggaran Dalam Sekolah sudah dilakukan } \\
\text { dengan efektif }\end{array}$ & & & & & & & & & & \\
\hline \multicolumn{12}{|c|}{ ME1.6 Tindakan Rerbaikan } \\
\hline 1 & $\begin{array}{l}\text { Maintenance yang dilakukan dalam Tata } \\
\text { Usaha sudah berialan sebagaimana } \\
\text { mestinya }\end{array}$ & & & & & & & & & & \\
\hline 2 & $\begin{array}{l}\text { Tata Usaha mampu melakukan perbaikan } \\
\text { berdasarkan pemantauan dan penilaian } \\
\text { pelaporan kineria }\end{array}$ & & & & & & & & & & \\
\hline
\end{tabular}




\begin{tabular}{|c|c|c|c|c|c|c|c|c|c|c|c|}
\hline \multirow[t]{2}{*}{ No } & \multirow[t]{2}{*}{ Pernyataan } & \multicolumn{5}{|c|}{ Performance } & \multicolumn{5}{|c|}{ Expectasi } \\
\hline & & SB & $\mathrm{B}$ & $\mathrm{C}$ & TB & STB & $\mathrm{SB}$ & $\mathrm{B}$ & $\mathrm{C}$ & TB & STB \\
\hline \multicolumn{12}{|c|}{ 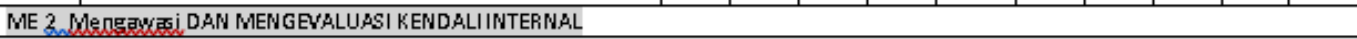 } \\
\hline \multicolumn{12}{|c|}{ 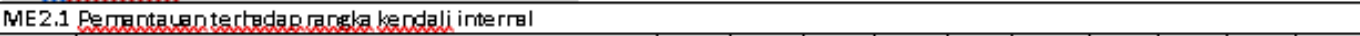 } \\
\hline 1 & $\begin{array}{l}\text { Bagaimana Pengawasan tingkat kendali } \\
\text { internal terhadap lingkungan Tata Usaha }\end{array}$ & & & & & & & & & & \\
\hline 2 & $\begin{array}{l}\text { Bagaimana Pengukuran tingakat kendali } \\
\text { untuk mencapai tujuan organisasi }\end{array}$ & & & & & & & & & & \\
\hline \multicolumn{12}{|c|}{ 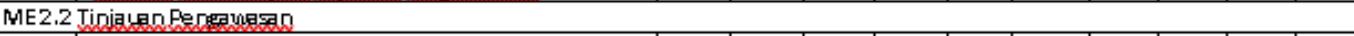 } \\
\hline 1 & $\begin{array}{l}\text { Efisiensi dalam peninjauan IT internal di } \\
\text { dalam Tata Usaha }\end{array}$ & & & & & & & & & & \\
\hline 2 & $\begin{array}{l}\text { Pengawasan efektifitas pengelolaan IT } \\
\text { internal dalam tata usaha }\end{array}$ & & & & & & & & & & \\
\hline \multicolumn{12}{|c|}{ 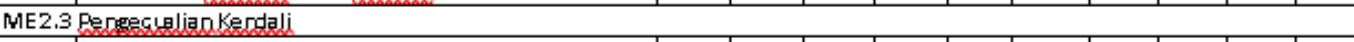 } \\
\hline 1 & $\begin{array}{l}\text { Dalam hal kendali keuangan tata usaha } \\
\text { terhadap sekolah sudah berialan dengan } \\
\text { aturan dan prosedur. }\end{array}$ & & & & & & & & & & \\
\hline 2 & $\begin{array}{l}\text { Identifikasipelaporan pencatatan biaua } \\
\text { yang di bayarkan dan digunakan dalam } \\
\text { sekolah sudah berialan dengan baik }\end{array}$ & & & & & & & & & & \\
\hline \multicolumn{12}{|c|}{ ME2,4 Kendalj Perrerikgag Diri } \\
\hline 1 & $\begin{array}{l}\text { Evaluasi Kelengkapan dan efektifitas } \\
\text { terhdap tata usaha }\end{array}$ & & & & & & & & & & \\
\hline 2 & Kontrak IT dalam Tata Usaha & & & & & & & & & & \\
\hline \multicolumn{12}{|c|}{ ME2.5 Janinan Dalan Kendalj Internal } \\
\hline 1 & $\begin{array}{l}\text { Jaminan Kendali internal Dalam tata } \\
\text { usaha sudah dilakukan dengan baik }\end{array}$ & & & & & & & & & & \\
\hline 2 & $\begin{array}{l}\text { Proses Kendali internal Dengan pihak } \\
\text { ketiga }\end{array}$ & & & & & & & & & & \\
\hline \multicolumn{12}{|c|}{ ME2.6 Kendali Interral Pada Pitrk Ketijg } \\
\hline 1 & $\begin{array}{l}\text { Penyedia Layanan eksternal dalam tata } \\
\text { usaha di sekolah sudah dilakukan dengan } \\
\text { baik }\end{array}$ & & & & & & & & & & \\
\hline 2 & $\begin{array}{l}\text { Persyaratan Legal Terhadap Tata Usaha } \\
\text { Sudah di jalankan dengan Baik }\end{array}$ & & & & & & & & & & \\
\hline \multicolumn{12}{|c|}{ 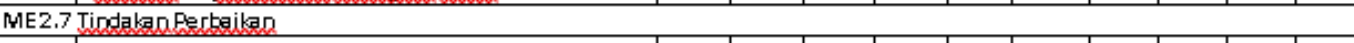 } \\
\hline 1 & $\begin{array}{l}\text { Penerapantindakanperbaikan dalam } \\
\text { Tata Usaha }\end{array}$ & & & & & & & & & & \\
\hline 2 & $\begin{array}{l}\text { Membuat perbaikan dalam system tata } \\
\text { usaha menjaditekomputerisasi }\end{array}$ & & & & & & & & & & \\
\hline
\end{tabular}




\section{(USER)}

Keterangan Pilihan Jawaban:

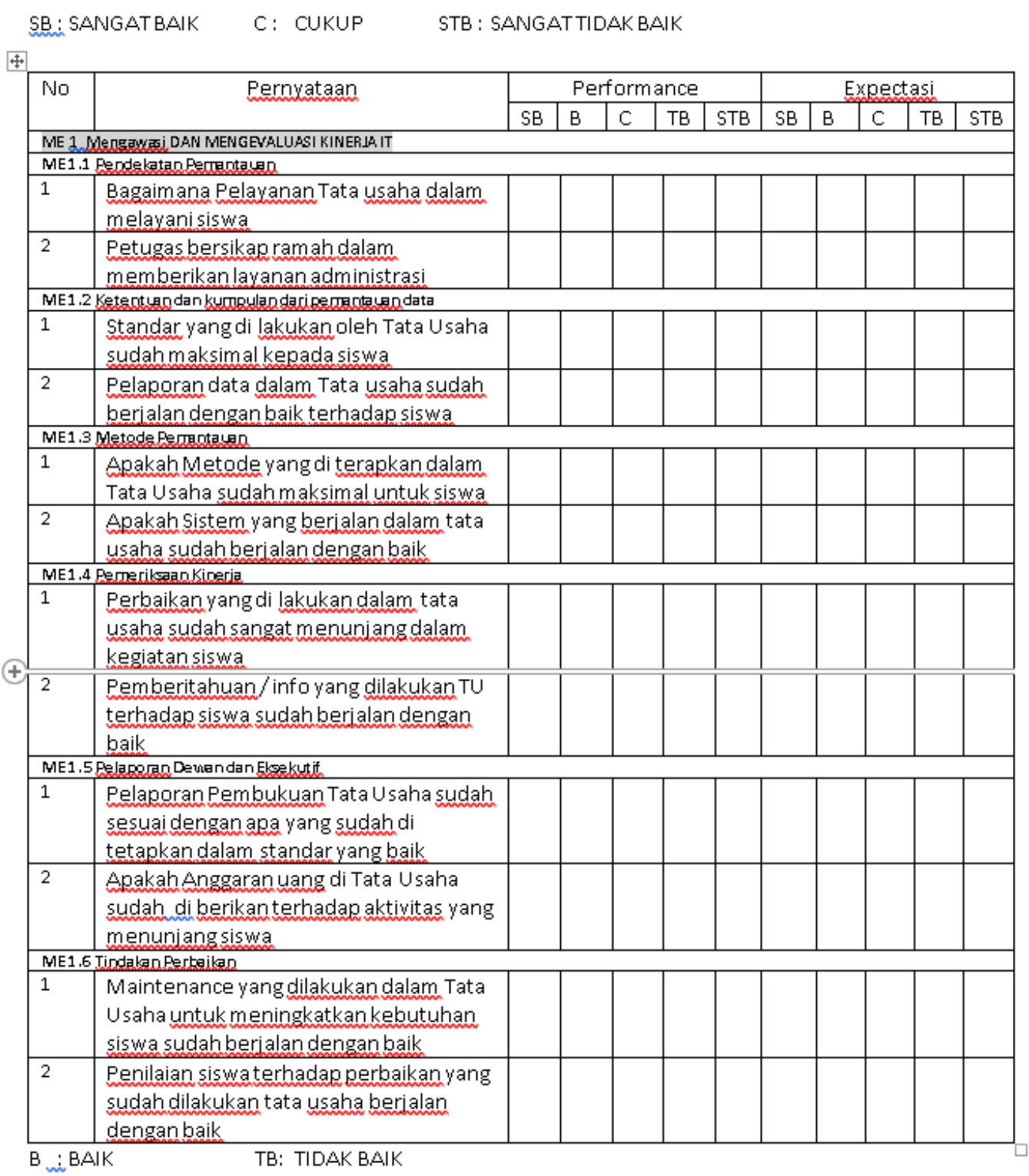




\begin{tabular}{|c|c|c|c|c|c|c|c|c|c|c|c|}
\hline \multirow[t]{2}{*}{ No } & \multirow[t]{2}{*}{ Pernyataan } & \multicolumn{5}{|c|}{ Performance } & \multicolumn{5}{|c|}{ Expectasi } \\
\hline & & $\mathrm{SB}$ & $\mathrm{B}$ & $\mathrm{C}$ & TB & STB & $\mathrm{SB}$ & $\mathrm{B}$ & $\mathrm{C}$ & TB & STB \\
\hline \multicolumn{12}{|c|}{ ME 2 Mengary } \\
\hline \multicolumn{12}{|c|}{ 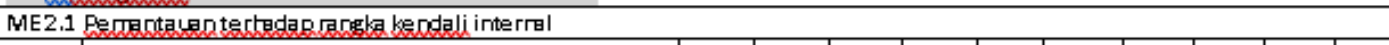 } \\
\hline 1 & $\begin{array}{l}\text { Apakah pengawasan Tata usaha } \\
\text { terhadap lingkungan sekolah sudah } \\
\text { efektif bagi siswa }\end{array}$ & & & & & & & & & & \\
\hline 2 & $\begin{array}{l}\text { Tujuan yang sudah berialan dalama Tata } \\
\text { usaha sudah dirasakan oleh siswa }\end{array}$ & & & & & & & & & & \\
\hline \multicolumn{12}{|c|}{ 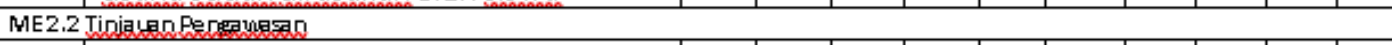 } \\
\hline 1 & $\begin{array}{l}\text { Penggunaan teknologi it dalam Tu untuk } \\
\text { siswa apakah sudah cukup baik }\end{array}$ & & & & & & & & & & \\
\hline 2 & $\begin{array}{l}\text { Pengawasan efektifitas pengelolaan IT } \\
\text { internal dalam tata usaha untuk siswa }\end{array}$ & & & & & & & & & & \\
\hline \multicolumn{12}{|c|}{ ME2.3 Eersegralian Kendeli } \\
\hline 1 & $\begin{array}{l}\text { Prosedur dan aturan dalam tata usaha } \\
\text { sudah berialan dengan baik bagi siswa }\end{array}$ & & & & & & & & & & \\
\hline 2 & $\begin{array}{l}\text { Identifikasipelaporan pencatatan biaya } \\
\text { yang di bayarkan dan digunakan dalam } \\
\text { sekolah sudah berialan dengan baik }\end{array}$ & & & & & & & & & & \\
\hline \multicolumn{12}{|c|}{ 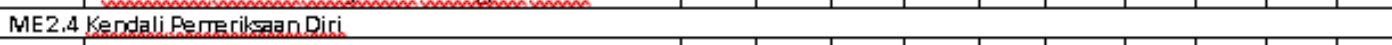 } \\
\hline 1 & $\begin{array}{l}\text { Petugas Tata Usaha bersedia diajak } \\
\text { berdiskusi mengenaikesulitan }\end{array}$ & & & & & & & & & & \\
\hline 2 & $\begin{array}{l}\text { Petugas melayani dengan waktu yang } \\
\text { efektif terhadap siswa }\end{array}$ & & & & & & & & & & \\
\hline \multicolumn{12}{|c|}{ ME2.5 Janinan Dalano Kendali Internal } \\
\hline 1 & $\begin{array}{l}\text { Petugas tidak memungut biaya luar } \\
\text { ketentuan sekolah }\end{array}$ & & & & & & & & & & \\
\hline 2 & $\begin{array}{l}\text { Tata usaha memberikan layanan dan } \\
\text { petuniuk tepat sesuaikebutuhan }\end{array}$ & & & & & & & & & & \\
\hline \multicolumn{12}{|c|}{ ME2.6 Kendali Internal Pada Pit } \\
\hline 1 & Toleransi Pembayaran terhadap siswa & & & & & & & & & & \\
\hline 2 & $\begin{array}{l}\text { Persyaratan dalam hal pembayaran spp } \\
\text { tahunan sudah bermusyawarahuntuk } \\
\text { menentukan biaya terhadap siswa }\end{array}$ & & & & & & & & & & \\
\hline \multicolumn{12}{|c|}{ 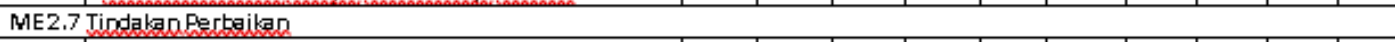 } \\
\hline 1 & $\begin{array}{l}\text { Tindakan Perbaikan dalam hal efisien } \\
\text { dalam dana bos untuk siswa }\end{array}$ & & & & & & & & & & \\
\hline 2 & $\begin{array}{l}\text { Membuat perbaikan dalam system tata } \\
\text { usaha menadiadekomputerisasi untuk } \\
\text { siswa }\end{array}$ & & & & & & & & & & \\
\hline
\end{tabular}




\section{BAB IV}

Proses Perhitungan Excel

\begin{tabular}{|c|c|c|c|c|c|c|c|c|c|c|c|c|c|c|c|c|c|c|c|}
\hline & \multicolumn{13}{|c|}{ REKAP HASIL KUESIONER } & & & & & & \\
\hline & \multicolumn{13}{|c|}{ USER } & & & & & & \\
\hline & & & & & & & & & & & & & & & & & & & \\
\hline & & & & & & & & & & & & & & & \multicolumn{2}{|c|}{\begin{tabular}{|l} 
PERFORMANCE \\
\end{tabular}} & \multirow{2}{*}{\multicolumn{2}{|c|}{\begin{tabular}{|l} 
EXPECTED \\
\end{tabular}}} & \multirow{3}{*}{ gap } \\
\hline & & \multicolumn{4}{|c|}{ PERFORMANCE } & & & & \multicolumn{2}{|c|}{ EXPECTED } & & & & & \multicolumn{2}{|c|}{ MATURITY } & & & \\
\hline & & No & SB & $\mathrm{B}$ & C & $T B$ & STB & ILH & $\mathrm{SB}$ & $\mathrm{B}$ & $\mathrm{C}$ & $\mathrm{TB}$ & STB & JLH & ACTVITA & PRIOSES & ACTIVITY & PROSES & \\
\hline 11 & ME 1.1 & 1.1 & 26 & 7 & 7 & & & 40 & 35 & 5 & & & & 40 & 11.93 & 1213 & 13.00 & 1300 & \\
\hline 2 & & 1.2 & 30 & 5 & 5 & & & 40 & 35 & 5 & & & & 40 & 12.33 & 12.15 & 13.00 & 10.00 & 0.87 \\
\hline 31 & ME 1.2 & 2.1 & 31 & 6 & 3 & & & 40 & 37 & 3 & & & & 40 & 12.53 & 1240 & 13.13 & 1320 & \\
\hline 4 & & 2.2 & 26 & 12 & 2 & & & 40 & 39 & 1 & & & & 40 & 12.27 & 12.40 & 13.27 & 10.20 & 0.80 \\
\hline 51 & ME 1.3 & 3.1 & 23 & 14 & 3 & & & 40 & 38 & 2 & & & & 40 & 12.00 & 12.00 & 13.20 & 13.23 & \\
\hline 6 & & 3.2 & 25 & 10 & 5 & & & 40 & 39 & 1 & & & & 40 & 12.00 & 12.00 & 13.27 & 10.25 & 1.23 \\
\hline $7 n$ & ME 1.4 & 4.1 & 34 & 2 & 4 & & & 40 & 37 & 3 & & & & 40 & 12.67 & 1237 & 13.13 & 1303 & \\
\hline 8 & & 4.2 & 28 & 5 & 7 & & & 40 & 34 & 6 & & & & 40 & 12.07 & 12.0 & 12.93 & 1000 & 0.67 \\
\hline 91 & ME 1.5 & 5.1 & 28 & 6 & 5 & 1 & & 40 & 37 & 3 & & & & 40 & 12.07 & 1220 & 13.13 & 1310 & \\
\hline 10 & & 5.2 & 29 & 7 & 4 & & & 40 & 36 & 4 & & & & 40 & 12.33 & 12.20 & 13.07 & 10.10 & 0.90 \\
\hline 111 & ME 1.6 & 6.1 & 22 & 11 & 7 & & & 40 & 35 & 5 & & & & 40 & 11.67 & 1217 & 13.00 & 1310 & \\
\hline 12 & & 6.2 & 33 & 4 & 3 & & & 40 & 38 & 2 & & & & 40 & 12.67 & t2. & 13.20 & 10.0 & 0.93 \\
\hline 131 & ME 2.1 & 1.1 & 29 & 10 & 1 & & & 40 & 39 & 1 & & & & 40 & 12.53 & 1220 & 13.27 & 1320 & \\
\hline 14 & & 1.2 & 24 & 12 & 2 & 2 & & 40 & 37 & 3 & & & & 40 & 11.87 & 12.20 & 13.13 & 10.20 & 1.00 \\
\hline 15 & ME 2.2 & 2.1 & 22 & 15 & 3 & & & 40 & 38 & 2 & & & & 40 & 11.93 & 1200 & 13.20 & 1320 & \\
\hline 16 & & 2.2 & 24 & 14 & 1 & 1 & & 40 & 38 & 2 & & & & 40 & 12.07 & 12.00 & 13.20 & 10.20 & 1.20 \\
\hline 17 & ME 2.3 & 3.1 & 27 & 11 & 2 & & & 40 & 39 & 1 & & & & 40 & 12.33 & 12.17 & 13.27 & 13.17 & \\
\hline 18 & & 3.2 & 26 & 8 & 6 & & & 40 & 36 & 4 & & & & 40 & 12.00 & & 13.07 & & 1.00 \\
\hline 191 & ME 2.4 & 4.1 & 27 & 7 & 5 & 1 & & 40 & 35 & 5 & & & & 40 & 12.00 & 118 & 13.00 & 1300 & \\
\hline 20 & & 4.2 & 20 & 15 & 5 & & & 40 & 37 & 3 & & & & 40 & 11.67 & 10.00 & 13.13 & 10.00 & $1.2 \mathrm{~s}$ \\
\hline 21 & ME 2.5 & 5.1 & 28 & 4 & 8 & & & 40 & 31 & 9 & & & & 40 & 12.00 & 118 & 12.73 & 1290 & \\
\hline 22 & & 5.2 & 21 & 15 & 1 & 3 & & 40 & 36 & 4 & & & & 40 & 11.60 & 10.00 & 13.07 & 12.00 & 1.10 \\
\hline 231 & ME 2.6 & 6.1 & 29 & 7 & 4 & & & 40 & 37 & 3 & & & & 40 & 12.33 & 1233 & 13.13 & 1317 & \\
\hline 24 & & 6.2 & 28 & 9 & 3 & & & 40 & 38 & 2 & & & & 40 & 12.33 & 12.00 & 13.20 & 10.18 & 0.83 \\
\hline 25 I & ME 2.7 & 7.1 & 32 & 7 & 1 & & & 40 & 39 & 1 & & & & 40 & 12.73 & 1260 & 13.27 & 1327 & \\
\hline 26 & & 7.2 & 29 & 9 & 2 & & & 40 & 39 & 1 & & & & 40 & 12.47 & 12.00 & 13.27 & 13.27 & 0.67 \\
\hline
\end{tabular}

REKAP HASIL KUESIONER MANAGEMENT

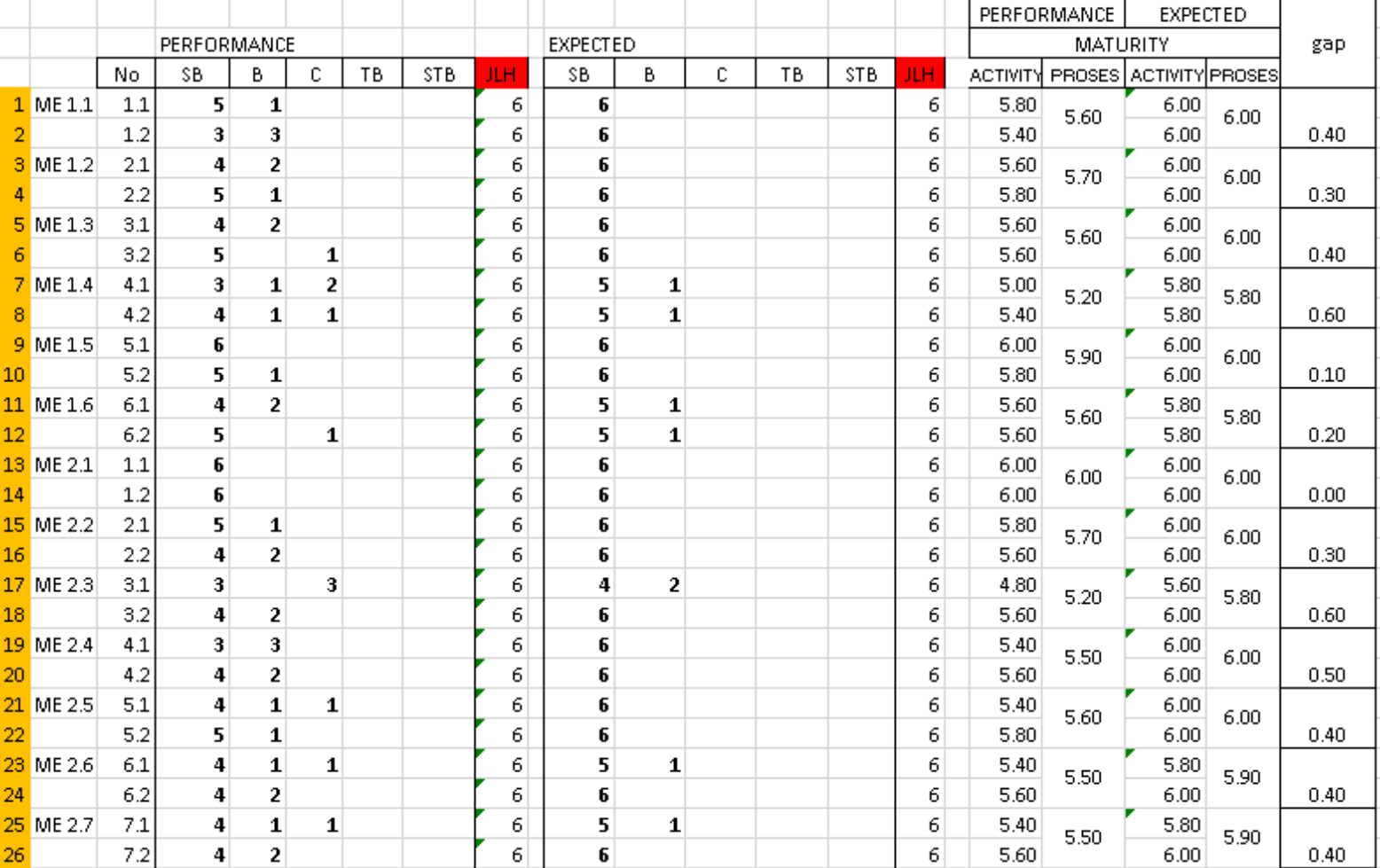




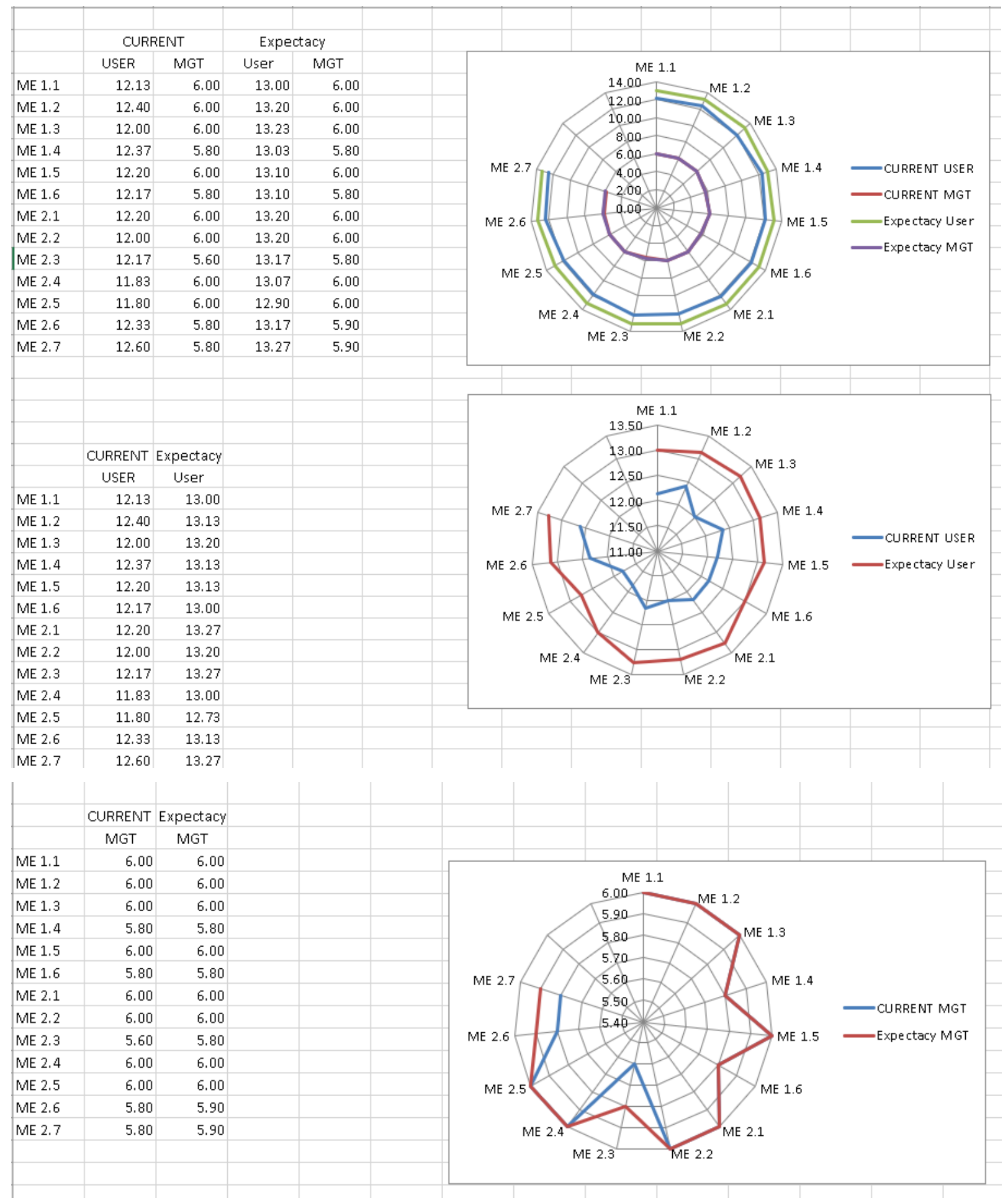




\section{BAB V}

KESIMPULAN \& SARAN

\section{A. Kesimpulan}

Berdasarkan hasil Audit Pada Tata Usaha SDN 1 Tanjung Sari Natar dapat Saya simpulkan sebagai berikut:

1. Kepemimpinan Kepala Tata Usaha di SD 1 Tanjung Sari Natar.

Kepemimpinan Kepala Tata Usaha mengedepankan musyawarah atau kepemimpinan yang demokratis. Setiap permasalahan yang di hadapi, Kepala Tata Usaha mengajak dengan Tenaga Kependidikan untuk bersamasama menyelesaikan permasalahan tersebut. Kepala Tata Usaha juga menerima masukan, kritik dan saran dari Tenaga Kependidikan. Namun demikian Kepala Tata Usaha SD 1 Tanjung Sari Natar.kurang tegas terhadap Tenaga Kependidikan. Misalnya saat ada Tenaga Kependidikan yang belum segera menyelesaikan pekerjaannya, Kepala Tata Usaha yang mengerjakannya. Selain itu saat Kepala Tata Usaha mendapatkan tugas dari Kepala Sekolah, Kepala Tata Usaha mengerjakan sendiri.

2. Kinerja Tenaga Kependidikan di SD 1 Tanjung Sari Natar.secara menyeluruh.

Kinerja Tenaga Kependidkan di SD 1 Tanjung Sari Natar. bermacam- macam, ada yang naik dan ada juga yang menurun. Untuk Tenaga Kependidikan yang sudah lama atau yang mau menjelang pensiun, biasanya menurun kinerjanya. Selain itu Tenaga Kependidikan yang sudah lama tidak diangkat menjadi PNS juga kadang menurun kinerjanya. 
Sedangkan untuk Tenaga Kependidikan yang masih baru, kinerjanya meningkat. namun demikian Kepala Tata Usaha berusaha memberi motivasi kepada Tenaga Kependidikan yang menurun kinerjanya, serta memberi tamabahan jadi bagi Tenaga Kependidikan yang meningkat keinerjanya.

3. Peran Kepala Tata Usaha dalam meningkatkan kinerja Tenaga SD 1 Tanjung Sari Natar..

a. Diskriminasi

Kepala Tat Usaha di SD Negeri sudah mampu membedakan antara Tenaga Kependidikan yang rajin dan Tenaga Kependidikan yang tidak rajin. Kepala Tata Usaha mengetahui hal tersebut dari penilaian. Penilaian dapat dilihat dari Tenaga Kependidikan menyusun rencana kerjanya awal tahun dan pada akhir tahun Kepala Tata Usaha menilai pelaksanaannya. Dari penilaian tersebut Kepala Tata Usaha melihat Tenaga Kependidikan sudah melaksanakan yang telah di rencanakan sebelumnya. Kepala Tata Usaha menilai bahwa Tenaga Kependidikan di SD 1 Tanjung Sari Natar.sudah melaksanakan yang telah direncanakan sebelumnya.

b. Penghargaan

Kepala Tata Usaha memberikan penghargaan dengan tambahan penghasilan bagi Tenaga Kependidikan yang meningkat kinerjanya. Selain tambahan penghasilan, Kepala Tata Usaha memberikan apresiasi dengan bercerita kepada orang lain bahwa kinerja dia (Tenaga Kependidikan yang meningkat kinerjanya) bagus. Meskipun 
Kepala Tata Usaha menyampaikan tidak secara langsung dengan orang yang bersangkutan, namun orang yang bersangkutan tersebut tahu dari orang yang diceritakan dari Kepala Tata Usaha.

c. Pengembangan

Usaha yang dilakukan oleh Kepala Tata Usaha dalam meningkatkan kinerja Tenaga Kependidikan melalui pelatihan. Kepala Tata Usaha mendapatkan kesulitan untuk meningkatkan kinerja melalui pelatihan bagi Tenaga Kependidikan yang sudaha lama atau yang menjelang pensiun. Namun begitu seandainya ada pelatihan dari pemerintah kabupaten bantul, Kepala Tata Usaha mengirimkan Tenaga Kependidikan yang masih baru untuk mengikuti pelatihan tersebut. Kepala Tata Usaha terbantu dengan adanya pelatihan bagi Tenaga Kependidikan. Dengan Tenaga Kependidikan mengikuti pelatihan, diharapkan bisa langsung praktik di sekolah.

d. Komunikasi

Kepala Tata Usaha berkomunikasi setiap tahun atau semester ada pembagian tugas bagi Tenaga Kependidikan. Kemudian untuk sehari-hari ada monitoring untuk Tenaga Tata Usaha, Tenaga Perpustakaan dan Tenaga Laboratorium. Kepala Tata Usaha lebih sering berkomunikasi dengan Tenaga Tata Usaha daripada dengan Tenaga Perpustakaan dan Tenaga Laboratorium. Karena Kepala Tata Usaha lebih banyak menghabiskan waktunya di ruang Tata Usaha. 


\section{B. Saran}

1. Kepada Kepala Tata Usaha di SD 1 Tanjung Sari Natar.

a. Sebaiknya Kepala Tata Usaha lebih tegas kepada Tenaga Kependidikan yang belum segera menyelesaikan tugasnya.

b. Sebaiknya Kepala Tata Usaha menbuat daftar penilaian bagi Tenaga Kependidikan yang tidak PNS, supaya bisa menjadi bahan evaluasi.

c. Saat Kepala Tata Usaha mendapatkan tugas dari Kepala Sekolah, Kepala Tata Usaha sebaiknya segera membagi tugas kepada Tenaga Kependidikan sesuai bidangnya.

d. Kepala Tata Usaha sebaiknya selalu berkomunikasi dengan Tenaga Perpustakaan dan Tenaga Laboratoium, supaya mengetahui kebutuhan apa saja yang diperlukan serta mengetahui kendala yang di hadapi.

e. Kepala Tata Usaha sebaiknya terus berusaha memberikan motivasi bagi Tenaga Tenaga Kependidikan yang menurut kinerjanya.

2. Kepada Tenaga Kependidikan di SD 1 Tanjung Sari Natar.

a. Untuk Tenaga Kependidikan yang sudah lama tidak diangkat menjadi PNS terus belajar untuk bisa mendaftar lagi dalam ujian CPNS selanjutnya. 


\section{DAFTAR PUSTAKA}

Gondodiyoto, S. (2007). Audit Sistem Informasi + Pendekatan COBIT. Edisi Revisi. Mitra Wacana Media. Jakarta.

Gondodiyoto, S. dan Henny H. (2006). Audit Sistem Informasi. MitraWacana Media, Jakarta.

Gondodiyoto, S. dan Henny H. (2007). Audit Sistem Informasi Lanjutan + Standar, Panduan, dan Prosedur Audit SI dari ISACA. Mitra Wacana Media, Jakarta.

Hall, James A. (2007). Sistem Informasi Akuntansi. Buku ke-2, edisi ke-4. Salemba Empat, Jakarta.

Hunton, James E., Bryant, Stephanie M., dan Bagranoff, Nancy A. (2004). Core Concepts of Information Technology Auditing. John Wiley \& Sons, Inc.

Jones, Frederick L. dan Rama, Dasaratha V. (2003). Accounting Information Systems, 


\section{LAMPIRAN}
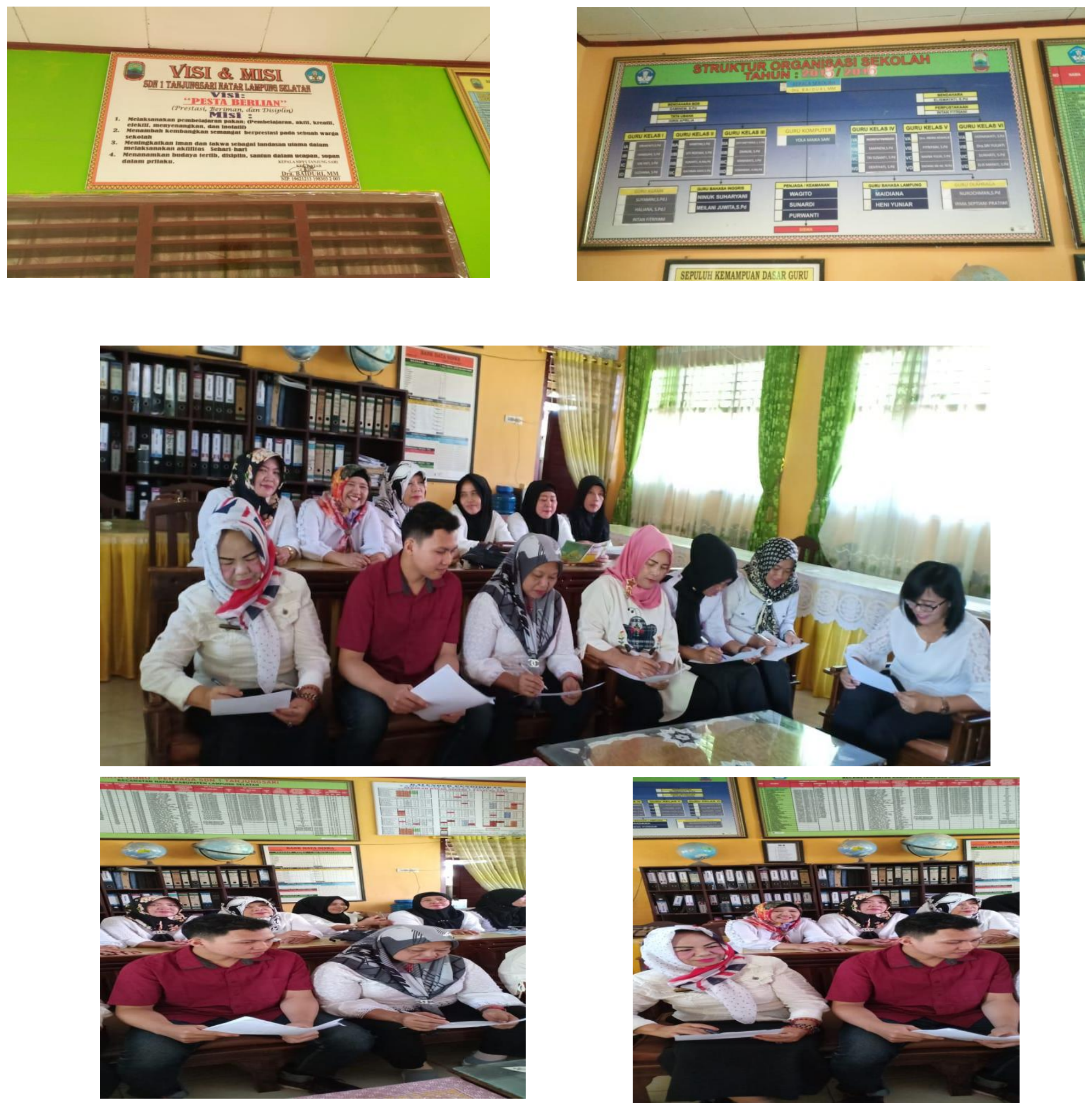


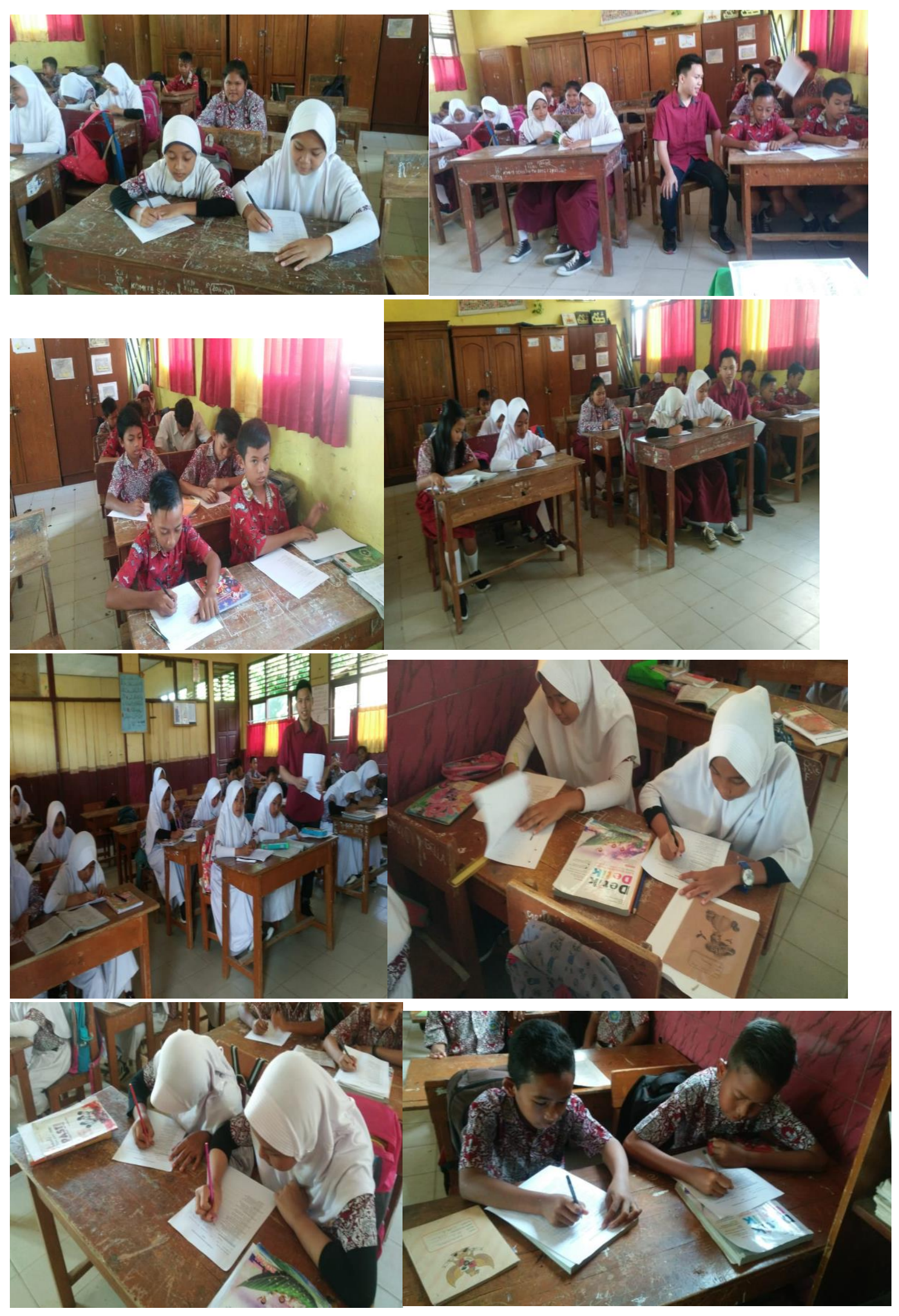



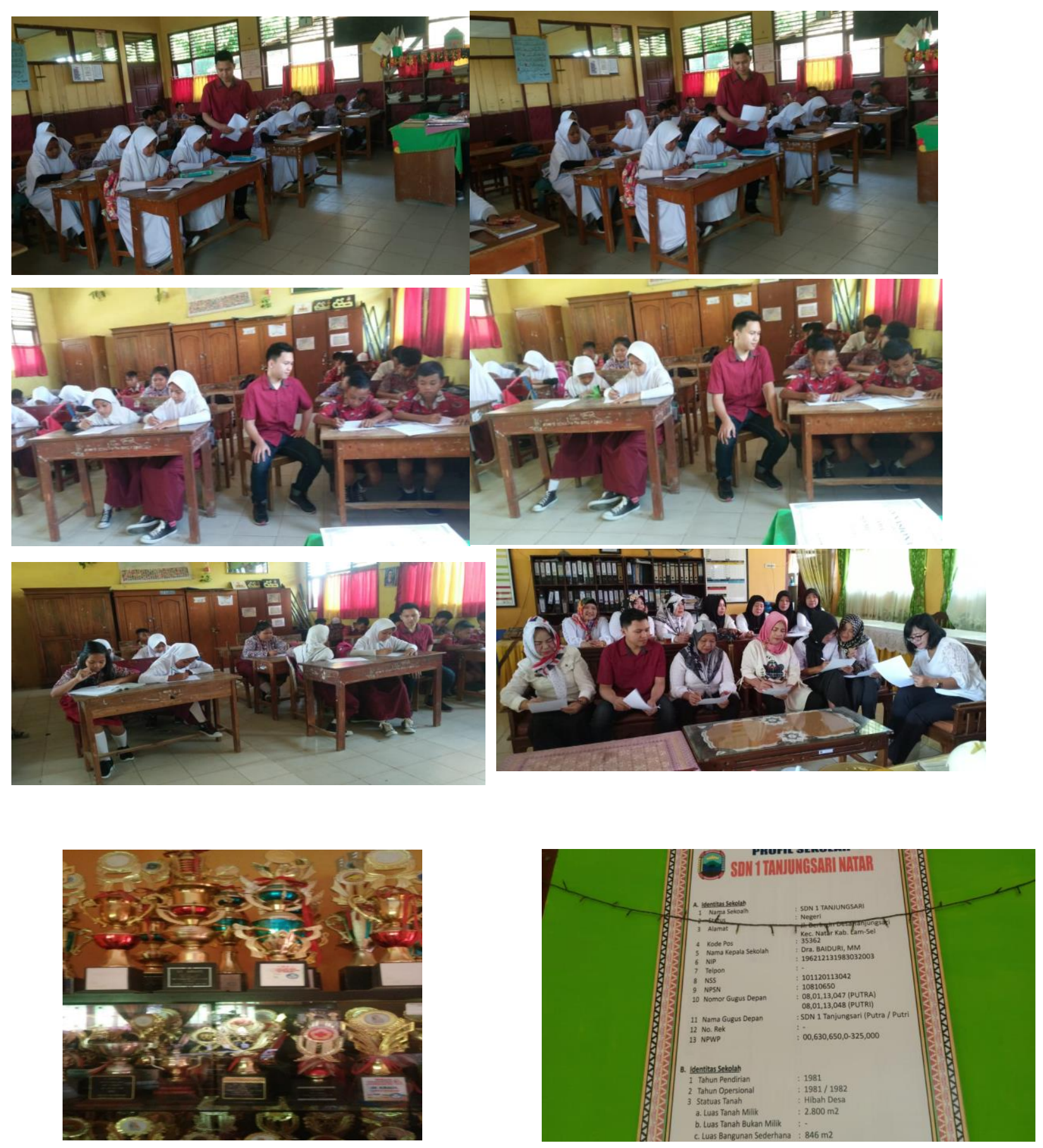